\title{
Pengembangan Media Pembelajaran Permainan Ular Tangga Edukatif Dalam Pembelajaran Sejarah Indonesia Masa Kolonialisme Dan Imperialisme Bangsa Eropa
}

\author{
Satriyo Pamungkas, Ulul Azmi \\ Universitas Batanghari Jambi, Indonesia \\ Correspondence email: satriyopamungkas2019@gmail.com
}

\begin{abstract}
Abstrak: Penelitian ini untuk mengetahui pengembangan media permainan ular tangga edukatif dalam pembelajaran sejarah Indonesia masa kolonialisme dan imperialisme bangsa Eropa menggunakan model Lee and Owens. Model pengembangan ini terdiri dari lima tahapan pengembangan yaitu analysis, design, development, implementation, and evaluation. Dari proses tahapan tersebut memperoleh rerata skor pada tahap uji coba yang produk melewati tiga tahapan yaitu one to one $(2,58)$ kategori kurang layak, small group $(4,2)$ kategori sangat layak, dan field test $(4,45)$ kategori sangat layak. Secara keseluruhan dari hasil uji coba tersebut memperoleh hasil rerata skor 3,74 kategori (layak).
\end{abstract}

Kata Kunci: Pengembangan, Media, Permainan Ular Tangga

Abstract: This study is to determine the development of educational media for playing snakes and ladders in learning the history of Indonesia during colonialism and European imperialism using the Lee and Owens model. This development model consists of five development stages, namely analysis, design, development, implementation, and evaluation. From the process of these stages, the average score at the trial stage where the product went through three stages, namely one to one (2.58) in the poor category, the small group (4.2) in the very feasible category, and the field test $(4,45)$ in the very category worth it. Overall from the results of these trials, the mean score was 3.74 categories (feasible).

Keywords: Development, Media, Snake and Ladder Game

\section{PENDAHULUAN}

Di Abad 21 saat ini, tanggung jawab guru bertambah dengan adanya perkembangan ilmu pengetahuan dan teknologi yang menghasilkan produk inovasi bermanfaat di masyarakat disegala aspeknya. Perkembangan ini menjadi konsekuensi guru bukan hanya sebagai pengajar tetapi dapat menjadi kreator dan inovator bagi siswa untuk berkreativitas. Dalam UU No. 20 Tahun 2003 pada pasal 40 ayat 2 menjelaskan bahwa guru berkewajiban menciptakan suasana pendidikan yang bermakna, menyenangkan, kreatif, dinamis, dan dialogis (Leo Agung, 2013:73). Mata pelajaran Sejarah Indonesia bertujuan agar siswa mengembangkan kemampuan berpikir historis (historical thinking) yang menjadi dasar untuk kemampuan berpikir logis, kreatif, inspiratif, dan inovatif.

Guna mencapai tujuan pendidikan peran guru mata pelajaran tidak hanya sebatas penyapaian materi namun juga mampu sebagai kreator dan inovator untuk membentuk kreativitas siswa melalui pembelajaran. Khususnya pada mata pelajaran sejarah Indonesia yang memiliki peran dalam pembentukan watak dan peradaban bangsa yang bermartabat serta dalam pembentukan manusia Indonesia yang memiliki rasa kebangsaan dan cinta tanah air. Namun, Permasalahan pokok dalam pembelajaran sejarah disebabkan karena rasa bosan, jenuh, hafalan, tidak menarik dan sebagainya (Suyono, 2013:9). Permasalahan demikian terjadi di SMA Negeri 9 Kota Jambi, dimana siswa merasa bosan, jenuh, dan tidak ada manfaatnya bagi mereka untuk masa depannya kelak. Walaupun guru telah berupaya dengan maksimal untuk mengurangi permasalahan tersebut dengan berbagai cara, seperti mengunakan media power point, video dan sebagainya.

Untuk mengurangi permasalahan tersebut, suatu permainan diajukan untuk pembelajaran sejarah sebagai solusi agar pembelajaran sejarah menarik serta memberikan kreativitas berpikir siswa guna memecahkan permasalahannya dan mampu bersaing di arus globalisasi. Karena dengan bermain seseorang akan merasa bebas, tidak ada paksaan, merasa senang namun serius. Bentuk permainan ular tangga diajukan namun berbeda, dimana gambar disesuaikan dengan materi dan cara memainkannya sehingga siswa merasa berbeda saat memainkannya dengan ular tangga tradisional. Kossyvaka \& Papoudi (Saputri, 2019:13) mengungkapkan bahwa bermain juga merupakan media yang baik untuk belajar karena menyenangkan, sukarela dan secara intrinsik memotivasi, fleksibel dengan orientasi nonliteral, dengan bermain anak-anak akan berkomunikasi yang membutuhkan keterlibatan aktif. Penelitian Nadlifatun (2015) mengangkat permasalahan mengenai rendahnya motivasi dalam pembelajaran sejarah. Produk media dari hasil pengembangannya mampu meningkatkan aktvitas siswa dan hasil belajarnya serta media pembelajaran permainan ular tangga sejarah membawa pengaruh positif, karena pembelajaran sejarah menjadi siswa lebih aktif $(94,6 \%)$, kreatif $(97,7 \%)$, menarik $(94,6 \%)$, mudah memahami materi $(93,1 \%)$, dan memotivasi peserta didik $(95,4 \%)$. 
Menurut Kossyvaki \& Papoudi (Saputri, 2019:13) menjelaskan bahwa bermain merupakan suatu media yang baik untuk belajar karena sukarela, dan secara intrinsik memotivasi, fleksibel serta komunikasi. Permainan ular tangga merupakan permainan tradisional yang sederhana namun menghibur, edukasi, berinteraksi antar pemain, serta meningkatkan ketertarikan siswa untuk belajar. Hasil penelitian Hasan\&Afriza (2017:755), The study results were obtained (1) the average percentage of media expediency questionnaire sheet from two validators was $100 \%$ which was in very proper category, (2) classically, the percentage of students' who gained mastery level was $80 \%$, and 3) the average percentage of students' response was $81,87 \%$ within very well category. To conclude, snake ladder game media could increase students' performance on the subject of compound's nomenclature.

Rumusan permasalahan yang diteliti adalah: 1) Bagaimanakah proses pengembangan media pembelajaran permainan ular tangga edukatif dalam pembelajaran sejarah pada materi perkembangan kolonialisme dan imperialisme bangsa Eropa di Indonesia? 2) Bagaimana kevalidan produk media pembelajaran permainan ular tangga edukatif dalam proses pembelajaran sejarah pada materi kolonialisme dan imperialisme bangsa Eropa di Indonesia dari ahli media dan meteri? 3) Apakah produk media pembelajaran permainan ular tangga edukatif dalam pembelajaran sejarah materi perkembangan kolonialisme bangsa Eropa di Indonesia layak untuk digunakan?

\section{METODE}

Penelitian ini merupakan jenis penelitian dan pengembangan (R\&D) sesuai dengan tujuannya yaitu untuk menghasilkan produk media permainan ular tangga edukatif untuk pembelajaran sejarah perkembangan kolonialisme dan imperialisme bangsa Eropa di Indonesia. Menurut Sugiyo penelitian dan pengembangan adalah metode penelitian yang digunakan untuk menghasilkan produk tertentu, dan mengkaji keefektifan produk tersebut (2014:297). Model pengembangan mengikuti tahapan model pengembangan Lee and owens yaitu ADDIE yang meliputi lima tahapan yaitu analysis, design, development, implementation, and evaluation (2004:3).

Pada tahap pertama yaitu analysis/analisis terdiri dari dua kegiatan yaitu analisis kebutuhan dan front-and analysis, tahap ini peneliti menggunakan metode observasi dan wawancara terhadap guru serta siswa. Hasil dari tahap ini dimana adanya kesenjangan dalam pembelajaran sejarah seperti guru sudah menggunkan media tetapi siswa merasa bosan, jenuh dan tidak bergairah dalam belajar. Kondisi siswa dalam belajar sejarah menginginkan adanya media lain yang dapat dimainkan bersama-sama dengan teman tanpa menggunakan alat teknologi, yang menarik dan menghibur sehingga belajar sejarah tidak monoton dan serius.

Berikutnya tahap desain, peneliti merancang serangkaian kegiatan sebagai pendukung pembuatan media pembelajaran. Pertama tim peneliti melakukan diskusi interen setelah itu dilanjutkan dengan diskusi bersama teman sejawat, dari hasil kegiatan ini peneliti memperoleh bentuk media yaitu berupa permainan ular tangga edukatif namun cara memainkannya berbeda. Pada tahap ini juga melakukan kegiatan merancang spesifikasi produk media yang akan dikembangkan beserta struktur materi dan perangkat instrumen validasi ahli serta pengguna untuk kelayakan media. Tahap ketiga development, pada tahap ini membuat media melalui aplikasi coreldraw untuk di wujudkan, setelah itu dilanjutkan dengan penilaian kelayakan tim ahli agar bisa di implementasikan, dan melakukan perbaikan. Tahap berikutnya implementation, tahap ini melakukan uji coba produk ke pengguna yaitu siswa kelas XI di SMA Negeri 9 Kota Jambi dengan serangkaian kegiatan yaitu one to one, small group, and field test. Dilanjutkan dengan pengisian angket oleh siswa, dan revisi untuk perbaikan. Terakhir tahap evaluation, tahap ini dilakukan mulai dari penilaian kelayak oleh tim ahli dilanjutkan dengan penilaian oleh pengguna melalui angket. Tahap dari setiap kegiatan ini dilakukan bersama-sama oleh tim supaya bisa saling membantu dan memberikan ide bersama-sama agar tercita produk media sesuai harapan.

\section{HASIL DAN PEMBAHASAN}

Pada model pengembangan Lee and Owens, tahap pertama adalah tahap Analysis.yang terdiri dari dua bagian kegiatan yaitu penilaian need assessment (analisis kebutuhan) dan front-end analysis (analisis awal akhir) (Lee \& Owens, 2004). Dibawah ini penjelasan pengembangan model Lee and Owens yang digunakan dalam penelitian pengembangan media pembelajaran permainan ular tangga edukatif.

1. Need Assessment (Analisis Kebutuhan)

Pada tahap analisis kebutuhan dalam penelitian dan pengembangan ini dilakuan dengan menerapkan metode wawancara dan observasi. Proses wawancara dilakukan terhadap guru mata pelajaran sejarah Drs. Sastri, M.Pd. sementara proses observasi dilakukan di SMA Negeri 9 Kota Jambi. Penggunaan dua metode tersebut bertujuan untuk mengetahui kesenjangan dalam proses pembelajaran dan memperoleh gambaran mengenai kondisi nyata di sekolah

2. Front-end Analysis (Analisis Awal dan Akhir)

Tahap ini bertujuan untuk memperoleh informasi mengenai apa yang akan dikembangkan. Ada beberapa informasi yang diperoleh pada tahap ini seperti karakteristik siswa dan informasi lain yang diperoleh dari siswa dimana guru sudah menggunakan media dalam aktivitas pembelajaran. Selain itu informasi menganai kelengkapan teknologi 
yang ada di sekolah sangat memadai dimana telah memiliki laboratorium komputer, labor fisika dan kimia, serta memiliki fasilitas proyektor di dalam kelas. Namun, media cetak yang dapat digunakan dalam proses pembelajaran sangat terbatas. Data lain yang diperoleh pada tahap ini yaitu kurikulum yang digunakan di sekolah SMA Negeri 9 Kota Jambi berupa kurikulum K13 edisi revisi. Perolehan data kurikulum bertujuan untuk mengetahui materi yang dianggap sulit atau materi yang dapat membentuk karakter siswa. Sehingga memperoleh gambaran mengenai apa yang menjadi isi materi serta menentukan media pembelajaran sebagai solusi.

\section{Tahap Kedua}

Tahap kedua adalah tahap design (desain), dimana pada tahap ini kegiatan merancang spesifikasi media yang akan dikembangkan dan merancang struktur materi yang akan munculkan melalui dalam media pembelajaran permainan ular tangga edukatif dalam pembelajaran sejarah berdasarkan diskusi tim peneliti dan diskusi dosen prodi dan teman sejawat. Pada tahap ini peneliti merancang tatacara permainan agar siswa tidak merasa bosan serta membuat soal pertanyaan yang berjumlah 30 soal yang terbagi menjadi 3 bagian yaitu "soal start", "soal tangga", dan "soal ular".

Tatacara memainkan media ular tangga edukasi dalam pembelajaran sejarah Indonesia masa kolonialisme dan imperialisme bangsa Eropa disusun sebagai berikut:

1. Permainan dilakukan oleh 2 - 4 pemain boleh kelompok maupun individu.

2. Para pemain memilih pions yang akan digunakan sebagai bidak.

3. Kocok tiga jenis kartu secara terpisah sebelum memulai permainan.

4. Setiap pemain harus bisa menjawab 1 pertanyaan agar dapat menjalankan pions.

5. Apabila pions pemain berhenti pada kotak tangga, maka pemain mengambil satu kartu tangga berisi soal yang harus dijawab agar bisa menaiki tangga. Namun jika tidak bisa menjawab, maka pions tetap berada di posisinya. Hal demikian berlaku untuk pions yang berhenti di dalam kotak ular. Pions tetap dalam posisinya apabila pemain bisa menjawab satu kartu soal ular. Jika pemain tidak bisa menjawab, maka pions harus turun.

6. Apabila pions berada di dalam satu kotak dan selanjutnya diikuti pions lain, maka pions pertama harus mengulang kembali dari start.

7. Apabila satu diantara pions pemain sampai pada kotak finish, maka menjadi pemenang dan mendapakan nilai tinggi dari pemain lainnya sebagai hadiah.

Adapun penggunaan media ular tangga edukatif bertujuan sebagai berikut:

1. Membuat pembelajaran menjadi lebih menarik.

2. Pembelajaran menjadi bervariasi.

3. Menciptakan suasana belajar yang tidak membosankan.

4. Membantu siswa dalam melakukan aktivitas sosial diantara siswa saat bermain.

5. Menciptakan kreatif siswa dalam berpikir.

Selanjutnya pertanyaan yang berada pada kartu start berjumlah 10 soal. Tujuan dari adanya kartu soal start ini untuk menciptakan keseruan saat memulai permainan. Berikut daftar pertanyaan/soal yang ada pada kartu start :

1. Apakah makna Semangat Reconcuesta?

Jawaban : semangat orang eropa terutama Spanyol untuk mengalahkan bangsa-bangsa yang pernah mengalahkan mereka pada perang salib yaitu orang - orang Islam, atau dengan kata lain semangat atau dorongan untuk melanjutkan perang salib.

2. Apa latarbelakang penjelajahan samudera bangsa Eropa dari segi politik?

Jawaban : Peristiwa jatuhnya kota Konstantinopel yang merupakan Ibu Kota Romawi Timur ke tangan Islam pada tahun 1453 sebagai rangkaian perang salib sehingga bangsa barat tidak bebas untuk berdagang karena dikenakan (bayar pajak, cukai, bea masuk). Kondisi demikian memaksa bangsa barat untuk mencari sumber rempah-rempah ke dunia timur.

3. Kenapa Indonesia menjadi daerah yang menjadi rebutan bangsa Eropa ?

Jawaban: Kekayaan bangsa Indonesia berupa rempah-rempah menjadikan bangsa Eropa ingin menguasai daerah penghasil rempah-rempah. Karena rempah-rempah merupakan komoditas perdagangan yang harganya tinggi di pasar Eropa.

4. Siapakan pimpinan armada laut Belanda saat berkunjung ke Indonesia setelah Cornelis De Houtman?

Jawaban : Tahun 1598 van Heemskerck

5. Apa tujuan Inggris membentuk East Indies Company (EIC)?

Jawaban : Inggris berusaha menjalin hubungan dengan kepulauan-kepulauan rempah-rempah agar hubungan tersebut bisa dijalankan dengan baik di Asia, Inggris membentuk East Indies Company (EIC). Menurut catatan 
sejarah kongsi dagang Inggris East India Company(EIC) sejak awal abad ke-17 telah mendirikan kantor-kantor dagangnya misalnya di Banten, Makassar, dan Maluku.

6. Jelaskan isi perjanjian Giyanti 13 Februari 1755 di Desa Giyanti ?

Jawaban: Isi pokok perjanjian itu adalah bahwa Mataram dibagi dua. Wilayah bagian barat (daerah Yogyakarta) diberikan kepada Pangeran Mangkubumi dan berkuasa sebagai sultan dengan sebutan Sri Sultan Hamengkubuwana I, sedang bagian timur (daerah Surakarta) tetap diperintah oleh Pakubuwana III dengan sebutan Kasunanan Surakarta.

7. Tahun berapakan VOC berhasil menguasai Malaka setelah mengalahkan saingannya, Portugis? Jawaban: Tahun 1641

8. Apa maksud dari devi de et impera ?

Jawaban: Politik adu domba yang dijalankan VOC agar terjadi peperangan sesama kerajaan yang ada di Indonesia.

9. Mengapa Portugis menaklukkan Malaka pada tahun 1511?

Jawaban : Portugis memiliki tujuan untuk memonopoli perdagangan di Malaka. Karena Malaka merupakan pusat perdagangan di Nusantara pada masa itu.

10. Spanyol pertama kali mendarat di Nusantara tepatnya di Maluku (Tidore) pada tahun 1521 yang dipimpin oleh? Jawaban : Juan Sebastian Delcano.

Berikutnya kartu pertanyaan tangga berjumlah 10 soal. Berikut daftar pertanyaan/soal yang ada pada kartu start:

1. Kenapa Indonesia menjadi daerah yang menjadi rebutan bangsa Eropa ?

Jawaban : Salah satu kekayaan nusantara yang menjadi daya tarik bagi orang asing ialah rempah- rempah diantaranya cengkeh, pala dan lada. Petualangan mencari rempah-rempah pada mulanya dijejaki oleh para pedagang dari India, Tiongkok, dan Arab sejak sebelum masehi. Rempah rempah dari Nusantara diperdagangkan ke kawasan Mediterania yang mula-mula dilabuhkan di Malabar (India). Lalu para pedagang India membawanya ke Roma dan Venesia. Setelah itu para pedagang Arab dengan perahu-perahu layarnya membawa rempah-rempah melintasi Laut Merah dan Teluk Persia.

2. Bangsa Eropa yang pertama kali sampai ke Nusantara adalah ? Jawaban : Bangsa Portugis

3. Pada tahun 1575 Portugis berhasil diusir dari Ternate oleh pasukan gabungan ternate dan tidore dibawah pimpinan?

Jawaban : Sultan Babullah

4. Kedatangan bangsa Belanda pertamakali di Nusantara terjadi pada tahun dan dibawah pimpinan?

Jawaban : Tahun 1596 dipimpin oleh Cornelis De Houtman di pelabuhan Banten.

5. Mengapa bangsa Eropa berburu rempah-rempah?

Jawaban : Karena rempah-rempah merupakan komoditi yang sangat laku di pasar Eropa, terlebih rempah-rempah digunakan sebagai persiapan untuk menghadapi perubahan musim di Eropa.

6. Perjanjian Zaragoza pada 1529 untuk mempertegas perjanjian Tordesillas tentang mana jatah wilayah Portugis dan mana jatah Spanyol.

Jawaban : Hasil perundingan Zaragosa menyebut wilayah Spanyol membentang dari Mexico barat sampai ke kepulauan Filipina, dan wilayah Portugis membentang dari Brazil ke timur sampai kepulauan Maluku. Maka secara de jure Maluku menjadi milik Portugis dan Spanyol memfokuskan kegiatan di Filipina yang telah ditemukan Magelhaens pada 1521 atas perintah Raja Karel V.

7. Salah satu bentuk konflik yang terjadi antara Belanda dan Ingris yaitu konflik di Jayakarta, apa yang menyebabkan terjadinya konflik tersebut?

Jawaban : Diizinkannya Ingris untuk membangun benteng oleh pangeran Jayakarta di tepi sungai ciliwung membuat VOC merasa keberatan dan berujung konflik bersenjata pada tahun 1618, konflik tersebut melibatkan armada Ingris. 15 kapal Ingris yang sedang berada di selat malaka dikerahkan untuk membantu pangeran jayakarta dan menyerang benteng VOC.

8. Apa fungsi didirikannya benteng bagi bangsa Eropa di Indonesia?

Jawaban : Disamping sebagai markas pertahanan dan kantor dagang, benteng-benteng tersebut juga berfungsi sebagai tempat tinggal masyarakat Eropa, yang oleh karena itu juga diberi sebutan sebagai kota-kota benteng.

9. Apa latar belakang penjelajahan samudera oleh bangsa barat dari segi ekonomi?

Jawaban : Latar belakang penjelajahan samudera dari segi ekonomi adalah Eropa sulit untuk berdagang maupun membeli rempah-rempah di pusat perdagangan Asia Barat dan keuntungan yang diperoleh sangat sedikit sehingga orang Eropa ingin mencari sumber dari rempah-rempah tersebut.

10.Bagaimana respon rakyat terhadap kedatangan bangsa Barat di Malaka?

Jawaban : Awalnya Portugis diterima di Malaka, namun Penaklukkan Malaka oleh Alfonso menyebabkan banyak protes dari berbagai kalangan hingga penguasa kerajaan Demak. Namun Portugis menjadi semakin kuat dan 
kemudian memperluas monopolinya sampai ke Indonesia.

Berikutnya kartu pertanyaan Ular berjumlah 10 soal. Berikut daftar pertanyaan/soal yang ada pada kartu start :

1. Mengapa kedatangan Belanda pertama diusir oleh penguasa Banten ?

Jawaban: Awalnya kedatangan mereka disambut dengan baik oleh kerajaan Banten, namun akhirnya diusir oleh penduduk pesisir Banten karena sikap mereka yang kasar dan sombong.

2. Apa latar belakang penjelajahan samudera dari segi idealisme?

Jawaban : Pada dasarnya penjelajahan bangsa eropa ke dunia timur memiliki idealisme sebagai tujuan utama mereka, tujuan mereka sama yaitu Gold, Glory dan Gospel.

3. Apa latar belakang penjelajahan samudera oleh bangsa barat dari segi perkembangan ilmu pengetahuan dan teknologi?

Jawaban : Berkembangnya teori Heliosentris, yang menyeutkan bahwa tata surya berpusat pada matahari, dan juga penemuan kompas, teleskop dan munculnya buku karangan Marcopolo yang menyebutkan bahwa ada kekayaan yang melimpah di negeri Timur.

4. Perjanjian Tordesillas berlangsung di Spanyol pada tanggal 7 Juni 1494, apa isi dari perjanjian tersebut?

Jawaban : Isinya adalah wilayah di luar Eropa dibagi menjadi dua dengan garis meridian $1550 \mathrm{~km}$ sebelah barat Kepulauan Tanjung Verde. Belahan sebelah timur dimiliki oleh Portugis dan belahan sebelah barat dikuasai Spanyol.

5. Apa alasan Belanda tidak lagi membeli rempah-rempah di Lisabon?

Jawaban : Karena penguasaan Lisabon jatuh ke tangan Spanyol yang sebelumnya dikuasai oleh Portugis dan Belanda membeli dagangan rempah-rempah dari Portugis di pusat pasar Lisabon.

6. Pada tahun berapakah kongsi dagang Belanda ini diberi nama Vereenigde Oost Indische Compagnie (VOC) berdiri?

Jawaban : Pada 20 Maret 1602 secara resmi dibentuk persekutuan kongsi dagang Belanda di Nusantara sebagai hasil fusi antar kongsi yang telah ada.

7. Ide untuk membentuk VOC ini dicetuskan oleh ?

Jawaban : Jacob van Oldebarnevelt, seorang pemuka masyarakat Belanda yang sangat dihormati.

8. Apa yang menyebabkan konflik antara Belanda dan Ingris terjadi di Jayakarta?

Jawaban : diizinkannya Ingris untuk membangun benteng oleh pangeran Jayakarta di tepi sungai ciliwung membuat VOC merasa keberatan dan berujung konflik bersenjata pada tahun 1618, konflik tersebut melibatkan armada Ingris. 15 kapal Ingris yang sedang berada di selat malaka dikerahkan untuk membantu pangeran Jayakarta dan menyerang benteng VOC.

9. Jelaskan arti penting dari Konstantinopel?

Jawaban : Konstantinopel merupakan pusat perdagangan di Asia dan Eropa, disanalah berbagai macam barang dagangan baik dari Asia maupun Eropa diperjual belikan. Bangsa Eropa awalnya mendapatkan pasokan rempahrempah dari Konstantinopel sebelum akhirnya mencari daerah Timur sebagai penghasil rempah-rempah.

10.Pada tahun berapakah Inggris mendirikan loji di Batavia?

Jawaban: Tahun 1614

\section{Tahap Ketiga}

Tahap ketiga adalah tahap mengaplikasikan rancangan desain ke software pendukung agar terwujudnya media pembelajaran permainan ular tangga edukatif. Pengembangan menggunakan software Corel Draw. Hasil dari proses ini yaitu berupa file print out media pembelajaran permainan ular tangga edukatif dalam pembelajaran sejarah yang siap untuk dicetak agar dapat dilakukan penilaian kelayakan dari tim ahli yang terdiri dari ahli media dan materi.

Di bawah ini adalah tampilan media pembelajaran setelah dilakukan dengan softwere Corel Draw untuk media pembelajaran permainan ular tangga edukatif pada pembelajaran sejarah khususnya untuk materi pembahasan mengenai kolonialisme dan imperialisme bangsa Eropa di Indonesia.

\section{Tahap Keempat}

Tahap keempat adalah tahap implementasi. Pada tahap ini, dilakukan validasi ahli media dan validasi ahli materi. Untuk validasi kelayakan media dilakukan oleh Dr. Mayasari M.Pd dan untuk validasi kelayakan materi oleh Nur Agustiningsih, M.Pd. Setelah produk dinyatakan layak oleh tim ahli, selanjutnya media diujicobakan kepada siswa. Dibawah ini hasil validasi kelayakan media pembelajaran oleh Ahli Media.

1. Validasi Ahli Media Tahap Pertama (Dr. Mayasari, M.Pd Tanggal 2 Juni 2020. 
Satriyo Pamungkas dan Ulul Azmi, Pengembangan Media Pembelajaran Permainan Ular Tangga Edukatif Dalam Pembelajaran Sejarah Indonesia Masa Kolonialisme Dan Imperialisme Bangsa Eropa

\begin{tabular}{llccc}
\hline No & Aspek & Jumlah Skor & Rerata & Kategori \\
\hline 1 & Materi & 14 & 3.5 & Layak \\
2 & Bahasa & 15 & 3.75 & Layak \\
3 & Warna & 15 & 3.75 & Layak \\
4 & Gambar & 18 & 3.6 & Layak \\
5 & Keaktivitas & 15 & 3.75 & Layak \\
\multicolumn{2}{r}{ Total Rerata } & & 3.67 & Layak \\
\hline
\end{tabular}

Sumber: Olahan data Primer

2. Validasi Ahli Media Tahap Kedua (Dr. Mayasari, M.Pd Tanggal 10 Juni 2020).

\begin{tabular}{llccl}
\hline No & Aspek & Jumlah & Rerata & Kategori \\
\hline 1 & Materi & 17 & 4.25 & Sangat Layak \\
2 & Bahasa & 18 & 4.5 & Sangat Layak \\
3 & Warna & 16 & 4 & Sangat Layak \\
4 & Gambar & 21 & 4.2 & Sangat Layak \\
5 & Keaktivitas & 17 & 4.25 & Sangat Layak \\
& & & 4,24 & Sangat Layak \\
\hline
\end{tabular}

Sumber: Olahan data Primer

Adapun komentar dan saran yang diberikan ahli media guna dilakukan revisi pada media pembelajaran sebagai berikut:

\begin{tabular}{lll}
\hline No & \multicolumn{1}{c}{ Komentar/saran perbaikan } & \multicolumn{1}{c}{ Tindakan } \\
\hline 1 & Berikan gambar pada backround & Sudah direvisi \\
2 & Tata letak yang lebih rapi & Sudah direvisi \\
3 & Warna agar tidak menggangu diantara komponen & Sudah direvisi \\
\hline
\end{tabular}

3. Validasi Pertama Ahli Materi (Nur Agustiningsih, M.Pd) Tanggal 17 Mei 2020

\begin{tabular}{lllll}
\hline No & Aspek & Jumlah & Rerata & Kategori \\
\hline 1 & Materi & 17 & 2.5 & Sangat Layak \\
2 & Bahasa & 18 & 2.5 & Kurang Layak \\
3 & Warna & 16 & 3 & Layak \\
4 & Gambar & 21 & 2 & Tidak Layak \\
5 & Keaktivitas & 17 & 2.75 & Kurang Layak \\
\multicolumn{2}{c}{ Total Rerata } & & 2,55 & Kurang Layak \\
\hline
\end{tabular}

Sumber: Olahan data Primer

4. Validasi Kedua Ahli Materi (Nur Agustiningsih, M.Pd) Tanggal 28 Mei 2020

\begin{tabular}{llcll}
\hline No & Aspek & Jumlah & Rerata & Kategori \\
\hline 1 & Materi & 31 & 4.5 & Sangat Layak \\
2 & Bahasa & 8 & 4 & Sangat Layak \\
3 & Warna & 10 & 5 & Sangat Layak \\
4 & Gambar & 9 & 4.5 & Sangat Layak \\
5 & Keaktivitas & 18 & 4.5 & Sangat Layak \\
& & & 4,5 & Sangat Layak \\
\hline
\end{tabular}

Sumber: Olahan data Primer

Tahap implementasi ini mencakup serangkaian kegiatan uji coba audiens yang terdiri dari uji coba one to one, small group, and field test. Pada Kegiatan uji coba melibatkan siswa sebagai subjek uji coba. Berikut tampilan media pembelajaran setelah melalui tahap implementasi kelayakan produk oleh tim ahli sebelum diterapkan uji coba lapangan.

\section{Uji coba One To One}

Kegiatan tahap ini merupakan uji coba produk yang dihasilkan dari uji kelayakan oleh tim ahli yang di cobagunakan ke siswa. Kegiatan dilakukan di sekolah SMA Negeri 9 Kota Jambi pada tanggal 27 Juni 2020 berjumlah tiga orang siswa. 
Satriyo Pamungkas dan Ulul Azmi, Pengembangan Media Pembelajaran Permainan Ular Tangga Edukatif Dalam Pembelajaran Sejarah Indonesia Masa Kolonialisme Dan Imperialisme Bangsa Eropa

\begin{tabular}{|c|c|c|c|c|}
\hline No & Aspek & Jumlah skor & Rerata & Kategori \\
\hline 1 & Tampilan & 31 & 2,58 & Kurang Layak \\
\hline 2 & Bahasa & 19 & 2,11 & Kurang Layak \\
\hline 3 & Warna & 27 & 2,25 & Kurang Layak \\
\hline 4 & Gambar & 16 & 2,67 & Kurang Layak \\
\hline 5 & Materi & 15 & 2,50 & Kurang Layak \\
\hline 6 & Keaktivitas & 40 & 2,67 & Kurang Layak \\
\hline \multicolumn{3}{|c|}{ Total Rerata } & 2.58 & Kurang Layak \\
\hline
\end{tabular}

Sumber: Olahan Data

Data komentar dan saran yang diberikan siswa untuk perbaikan media pembelajaran sebagai berikut:

\begin{tabular}{cllc}
\hline Siswa & \multicolumn{1}{c}{ Komentar / Saran Perbaikan } & Tindakan \\
\hline 1 & 1). Pemilihan warna. 2). Dadu yang menarik & Sudah direvisi \\
2 & $\begin{array}{l}\text { 1). Angka diperjelas. 2). penggunaan warna bervariasi. 3). Dadu yang menarik. } \\
\text { Pertanyaan yang sesuai materi. 5) gambar yang menarik. }\end{array}$ & Sudah direvisi \\
3 & $\begin{array}{l}\text { 1). Angka di kotak agar diperjelas. 2. Dadu yang menarik. 3. harus ada hukuman bagi yang } \\
\text { tidak bisa menjawab soal. }\end{array}$ & Sudah direvisi \\
\hline
\end{tabular}

\section{Uji Coba Small Group}

Kegiatan tahap ini merupakan uji coba produk yang dihasilkan dari revisi pada tahap uji coba one to one. Kegiatan dilakukan di sekolah SMA Negeri 9 Kota Jambi pada tanggal 27 Juli 2020 berjumlah 14 orang siswa.

Sumber: Olahan Data Small Group

\begin{tabular}{clccc}
\hline No & Aspek & Jumlah skor & Rerata & Kategori \\
\hline 1 & Tampilan & 205 & 3,7 & Layak \\
2 & Bahasa & 120 & 4 & Sangat Layak \\
3 & Warna & 161 & 3.82 & Layak \\
4 & Gambar & 128 & 4.36 & Sangat Layak \\
5 & Materi & 128 & 4.57 & Sangat Layak \\
6 & Keaktivitas & 311 & 4.44 & Sangat Layak \\
\multicolumn{2}{c}{ Total Rarata } & & 4.2 & Sangat Layak \\
\hline
\end{tabular}

\section{Uji Coba Field Group}

Kegiatan tahap ini merupakan uji coba produk yang dihasilkan dari revisi pada tahap uji coba one to one. Kegiatan dilakukan di sekolah SMA Negeri 9 Kota Jambi pada tanggal 27 Juli 2020 berjumlah 14 orang siswa.

Sumber: Olahan Data Small Group

\begin{tabular}{llccc}
\hline No & Aspek & Jumlah skor & Rerata & Kategori \\
\hline 1 & Tampilan & 444 & 4,44 & Layak \\
2 & Bahasa & 330 & 4,4 & Sangat Layak \\
3 & Warna & 434 & 4,34 & Layak \\
4 & Gambar & 223 & 4,46 & Sangat Layak \\
5 & Materi & 228 & 4,56 & Sangat Layak \\
6 & Keaktivitas & 564 & 4.51 & Sangat Layak \\
& Total Rerat & & 4.45 & Sangat Layak \\
\hline
\end{tabular}

\section{Tahap Kelima}

Tahap kelima adalah tahap evaluasi, pengembang dalam kegiatan ini melakukan evaluasi terhadap produk media pembelajaran permainan ular tangga edukatif untuk pembelajaran sejarah Indonesia masa kolonialisme dan imperialisme bangsa Eropa berorientasi pada kelayakan media yang dikembangkan melalui validasi ahli media, ahli materi serta hasil uji coba produk. Tahap evaluasi ini berkaitan dengan tahap sebelumnya, yaitu tahap keempat. Tahap evaluasi dilakukan setelah masing-masing serangkaian kegiatan di tahap keempat (validasi ahli dan uji coba produk) dilakukan. Tahap evaluasi dilakukan berdasarkan hasil validasi ahli dan uji coba produk.

\section{HASIL DAN PEMBAHASAN}

Data tahapan uji coba pruduk yang meliputi tiga tahap yaitu tahap one to one memperoleh hasil rerata 2.58 dalam kategori kurang layak, tahap small group memperoleh 4.2 kategori sangat layak, dan tahap field test memperoleh data 4.45 kategori sangat layak. Dari keseluruhan data hasil uji coba tersebut, memperoleh hasil skor 
kelayakan sebesar 3,74. Maka dapat disimpulkan kelayakan media permainan ular tangga edukatif dalam pembelajaran sejarah Indonesia masa kolonialisme dan imperialisme bangsa Eropa tergolong kategori layak digunakan karena memperoleh hasil akhir 3,74.

Kossyvaki \& Papoudi (Saputri, 2019:13) memberikan penjelasan bermain merupakan suatu media yang baik untuk belajar karena sukarela, dan secara intrinsik memotivasi, fleksibel serta komunikasi. Maka, permainan ular tangga merupakan permainan tradisional yang sederhana namun menghibur, edukasi, berinteraksi antar pemain, serta meningkatkan ketertarikan siswa untuk belajar. Hasil penelitian Hasan\&Afriza (2017:755), The study results were obtained (1) the average percentage of media expediency questionnaire sheet from two validators was $100 \%$ which was in very proper category, (2) classically, the percentage of students' who gained mastery level was 80\%, and 3) the average percentage of students' response was $81,87 \%$ within very well category. To conclude, snake ladder game media could increase students' performance on the subject of compound's nomenclature. Penelitian Nadlifatun (2015) mengangkat permasalahan mengenai rendahnya motivasi dalam pembelajaran sejarah. Produk media dari hasil pengembangannya mampu meningkatkan aktvitas siswa dan hasil belajarnya serta media pembelajaran permainan ular tangga sejarah membawa pengaruh positif, karena pembelajaran sejarah menjadi siswa lebih aktif $(94,6 \%)$, kreatif $(97,7 \%)$, menarik $(94,6 \%)$, mudah memahami materi $(93,1 \%)$, dan memotivasi peserta didik $(95,4 \%)$.

\section{SIMPULAN}

Pengembangan media pembelajaran permainan ular tangga edukatif dalam pembelajaran sejarah Indonesia masa kolonialisme dan imperialisme bangsa Eropa telah melalui tahapan model pengembangan Lee and Owens yang terdiri dari lima tahapan yaitu, analysis, design, development, implementation, and evaluation. Dari tahapan tersebut memperoleh hasil data uji coba sampai tahapan uji lapangan memperoleh rerata skor akhir 3,74 kategori Layak.

\section{DAFTAR PUSTAKA}

Agung, Leo. 2013. Perencanaan Pembelajaran Sejarah. Yogyakarta: Ombak.

Sugiyono. 2014. Metode Penelitian Kuantitatif, Kualitatif, dan R\&D. Bandung: Alfabeta

Habibati, M. Hasan and Ria Afriza, The Development Of Snake Ladder Game Media In Compound's Nomenclature Subject For Tenth Graders At Sman 16 Banda Aceh. (Artikel. Proceedings of The 7th Annual International Conference (AIC) Syiah Kuala University and The 6th International Conference on Multidisciplinary Research $(I C M R)$ in conjunction with the International Conference on Electrical Engineering and Informatics (ICELTICs) 2017, October 18-20, 2017, Banda Aceh, Indonesia).

Siswoyo. 2015. Pengembangan Alat permainan Edukatif Ular Tangga Matematika Pokok Bahasan Luas Bangun Datar Untuk Siswa Kelas V SDN 1 Sinduadi Milati Sleman. Artikel Jurnal Teknologi Pendidikan Vol. 5 (1): 1-12.

Saputri, Herliana Rahmi, Pengembangan Permainan Ular Tangga Modifikasi (Socio Snake And Ladder) Untuk Meningkatkan Social Skill Anak Intellectual Developmental Disorder (Idd) Ringan, (Tesis. Universitas Muhammadiyyah Malang, 2019:5). 